This article was downloaded by: [University of Sydney]

On: 01 May 2015, At: 19:15

Publisher: Routledge

Informa Ltd Registered in England and Wales Registered Number: 1072954

Registered office: Mortimer House, 37-41 Mortimer Street, London W1T

3J H, UK

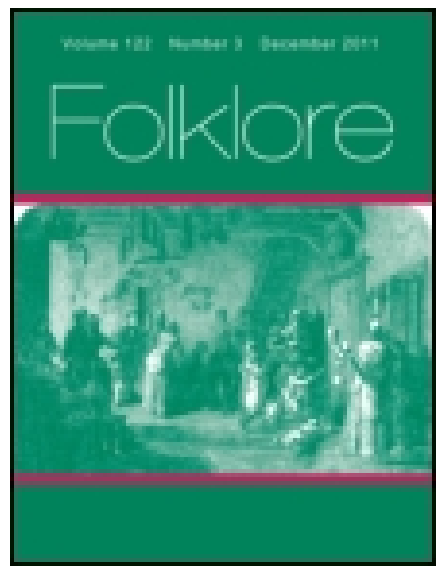

\title{
Folklore
}

Publication details, including instructions for authors and subscription information:

http:// www. tandfonline.com/loi/ rfol20

\section{Fairy Gold}

W. H. D. Rouse, N. W. Thomas, Malcolm Macphail , J ohn H. Barbour , A. B. Gomme \& S. O. Addy Published online: 14 Feb 2012.

To cite this article: W. H. D. Rouse, N. W. Thomas, Malcolm Macphail , J ohn H. Barbour , A. B. Gomme \& S. O. Addy (1897) Fairy Gold, Folklore, 8:4, 379-396, DOl: 10.1080/ 0015587X.1897.9720431

To link to this article: http:// dx.doi.org/ 10.1080/ 0015587X.1897.9720431

\section{PLEASE SCROLL DOWN FOR ARTICLE}

Taylor \& Francis makes every effort to ensure the accuracy of all the information (the "Content") contained in the publications on our platform. However, Taylor \& Francis, our agents, and our licensors make no representations or warranties whatsoever as to the accuracy, completeness, or suitability for any purpose of the Content. Any opinions and views expressed in this publication are the opinions and views of the authors, and are not the views of or endorsed by Taylor \& Francis. The accuracy of the Content should not be relied upon and should be independently verified with primary sources of information. Taylor and Francis shall not be liable for any losses, actions, claims, proceedings, demands, costs, expenses, damages, and other liabilities whatsoever or howsoever caused arising directly or indirectly in connection with, in relation to or arising out of the use of the Content.

This article may be used for research, teaching, and private study purposes. Any substantial or systematic reproduction, redistribution, reselling, loan, sub-licensing, systematic supply, or distribution in any form to anyone is 
expressly forbidden. Terms $\&$ Conditions of access and use can be found at http://www.tandfonline.com/page/terms-and-conditions 


\section{MISCELLANEA.}

\section{FAIRY GoLd.}

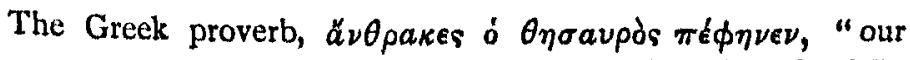
treasure turned out to be charconl," seems to show that the folktale episode of the "fairy gold" was current in ancient Greece. $\Lambda$ number of Grcek proverbs have origin in the fables, and this may be similar.

IV. H. D. Roust.

\section{Couvade.}

The following notices of the couvade may be interesting :-

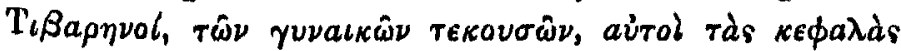

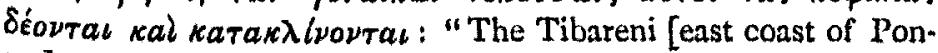
tus], when their wives bring forth, themselves tie up their heads and lie in." Corpus Paroem. Gr., p. 127. So Apollonius Rhodius, ii. roro: "The Tibarenian land, where, when wives bring forth children, the husbands fall on their beds and groan, binding up their heads, while the wives carefully wait on their men with food, and bring to them the water for washing at childbirth."

\section{W. H. D. RousE.}

\section{A Folktalet concerning Jesus Curist.}

In 1869 a lady, visiting a poor woman in South-east Lancashire, turned the conversation to Christianity. The woman at first said she had never heard of Christ. Afterwards she asked if it were not he who once went to a poor woman's door; when he asked for food she replied that even then she was boiling stones in the pot to make her children believe they were peas. Christ replied by telling her to lift the lid, which she did, and found the pot full of peas. 
My informant also states that the woman had heard of some connection between Christ and the cuckoo; it was, perhaps, that he came with the cuckoo.

N. W. Thomas.

\section{FOLKLORE FROM THE HEBRIDES.-II}

1.--Sithichean, sithean Chaipighill. (The Fairies of the Fairy Knoll of Caipighill.) Caipighill is a Norse word, the meaning of which I don't know. Caipighill, Shawbost, parish of Lochs, Lewis.

The fairy legend associated with the two Caipighill knolls is the following. $\Lambda$ woman who happened to be passing between these two hillocks one hot summer day heard the sound of churning in the fairy knoll (chuala i fuaim maistreaidh anns an t-sitheain). She said (sotto voce): "Is truagh nach robh mo phathadh air bean a' ghlugain" ("It is a pity my thirst was not on the churning woman "). ("Glug" is the noise of fluid in motion, but confined in a vessel.) No sooner had the words escaped her lips than a fairy woman (a bean shith) attired in green came out of the "sthean" with a drinking cup (a 'cuach) of buttermilk in her hand, and offered it to the woman to drink. At this sudden and unexpectud answer to her wish she felt a good deal put out, and declined the fairy's hospitality, giving as her reason for so doing that she was not thirsty. "Why then did you wish for it ?" said the fairy woman ("Carson mata a $\mathrm{dh}$ ' iarr thu $\mathrm{i}$," arsa' bhean shith). Observing the woman's embarrassment, she said: "Are you afraid it will injure you?" ("Thubhairt $i$ am bheil eagal ort gu'n dean i cron dhuit"). "Yes," she said ("Tha" ars' ise). "The misfortune of her who put the first comb in her head on Wednesday be mine if it will do you any harm" ("Galar na te a chuir a'cheud chir cheud-noin'na ceann armsa ma ni $i$ cron ort"). "What misfortune is that?" said she. "The misfortune of having neither son, nor daughter, nor grandchild, nor great-grandchild" ("Coid an galar a tha'n sin?" ars ise. "Iha arsa' bhean-shith, galar a bhi gun mhac, gun nighean, gun odha, gun iar-odha ")."

I I once related the alsove fairy legend where a Cerman happened to be present. "Llow strange!" he remarked. "I have been familiar with that legend from childhood in my native country." 
This legend is of some interest philologically, as it indicates that IVednesday (Di-ciadain) was the day of the first fast. Thursdiny (I)inr-dnoin) the day after the fast. Friday (Di-h-aoine) the filst-day. The legend clearly shows that these days of the weck clerived their names from "noin" (a fast), and that these fastdiays were considered so sacred that the first woman who ventured to comb her hair on a Wednesday was believed to have been punished with sterility for her profanity. (I was acquainted with some people in my young days who would not comb their hair on Sunday.) This view is strongly corroborated by a Lewis proverb: "O aoin gu h-an-aoin," i.e. "From the calmness of sacred fast to the most admired disorder." It was considered unlucky to marry on Friday, and even at the present day Thursday is the day usually selected for "tying the nuptial knot." In reading the Apostolical Constitution a few months ago I discovered that Wednesday and Friday were held as sacred fast-days, as the subjoined note shows :

"Wednesday and Friday Fasts.-The reason for fasting on the days specified is given in the Apostolical Constitution thus: because on the fourth day judgment went forth against the Lord, Judas then promising his betrayal for money, and on the preparation (fast), because the Lord suffered on that day the death of the cross." (The Church of the Sub.Apostolic Age, by Professor Itcron, p. I85.)

\section{II.-Sithichean Cnocmir Arnol. (The Fairies of the big Rnoll of Arnol.) Arnol, parish of Barvas, Lewis.}

The fairies of the Cnoc-mor and the family who lived in the immediate neighbourhood of the "Bruth" (dwelling of fairies) were on such good terms as neighbours that the same "coire" (boiler) did duty for both establishments. The "coire," however, was not the property of the fairies, but of the family of the Adamic race. When the fairies got the use of the "coire" in loan it was a sine qua non to their returning it safely at the ap. pointed time, that the person who handed it to them said as bo did so: "Dleasaidh coire cneimh, 'us a chur slan d'a thigh" (" $\Lambda$ boiler merits a bone and returning it safely home"). Things went on thus pleasantly and neighbourly enough between the "Bruth" dwellers and the family for some time. One day, however, as the 
good wife, in the absence of her husband, handed the "coire" to the fairies, she forgot to repeat the talismanic rhyme: "Dleasaidh coire cnèimh, 'us a chur slìn d'a thigh" (" $\mathrm{A}$ boiler merits a bone and returning it safely home"), that acted so magically on the fairies as to oblige them, nolentes volentes, to return it at the proper time. This talismanic rhyme is a common proverb with the addjtion " 'Us dleasaidh gobha gual, 'us iarruin fuar ga' bhleith " ("A smith merits coal and cold iron to grind ").

Although she forgot to repeat the rhyme, the fairies did not. As the "coire" was not returned at the usual time she was obliged to go for it to the "Bruth." On her arrival there the door happened to be wide open. Seeing the "coire" at a short distance from the door she went straight for it without saluting the "Bruth" dwellers (Gun bheannachadh do mhuinntir a' Bruth), and unceremoniously seized it and made for the door. As she did so she heard one of the fairies saying: " $A$ ' bhean bhalbh sin 'us a' bhean bhalbh sin a thainig a tir nam fear màrbh fuasgal ' $A n$ Dubh' 'us leig " $A$ n Dearg'" ("That dumb woman, that dumb woman, who came from the land of the dead men. Open 'the Black' and let go 'the Red'"). Just as she was going out at the door "the Dubh" seized her by the heel and tore it off. She died so shortly thereafter (so says the legend) that she had scarcely time to tell of the treatment she had received at the hands of her neighbours of the "Bruth." I have often heard of the "cutth sith," the fairy dog ; but this is the only legend I know in which the names of any fairy dogs occur.

\section{III.-The Deer an Animal of Evil Omen.}

One of the old pagan beliefs which has come down to our own times, but which one scarcely hears mentioned at the present day, was, that If a deer were seen, or met one, in a place unfrequented by deer and separated from the herd, such an event was considered of old a certain forerunner of some catastrophe that was shortly to overtake the individual who had seen the deer, or to take place in that locality. The writer remembers as a dream, but quite distinctly, of some of his old intimate acquaintances associating the fact that a deer had been seen in a locality unfrequented by deer with a drowning that had shortly thereafter taken place there, and which happened at the time to be a subject of 
public talk. The one event was to them a prophecy of the other, and a thing that might have been looked for. The deer, it was said, had been seen running towards the sea, in the direction of the spot where the drowning had occurred, and where no deer had been seen within the memory of then living man. This superstition had taken such a hold of the popular mind that it shaped itself into one of their most common proverbs: "Tachraidh d' fhiadh fhéin riutsa thathast Lit" (Your own deer will meet you yet). Paraphrased, and as applied to one profane of speech and reckless of conduct, it is meant to convey to the individual addressed that his daring impiety is a sure precursor of a sudden overthrow.

\section{IV. - The Deer of the Island of Lochlacsvat-Carloway, Lewis.}

The following deer legend is somewhat similar to the preceding one. The circumstances under which the deer was beheld in this legend are as follows:

Two brothers (clannan t-saoir, the carpenter's sons) were out hunting in the neighbourhood of Lochlacsvat. They observed a deer grazing on the island. One of them swam across to the island. On landing, however, no deer was to be seen anywhere on the island. He returned to the mainland. No sooner had he reached the shore than he saw the deer again, just where he had seen it before. He immediately swam back to the island, but could neither find, nor see any traces of, the deer. On his return* ing back he became exhausted and was drowned. A similar story is associated with an island on Lachlangvat, a loch between Lewis and Harris.

To see a deer under such circumstances as described in the above legend was called, in superstitious phraseology, one's "manadh," i.e. an omen of one's death.

\section{V.-An Each Visge. (The Water-horse.)}

The "Each Uisge" at Carishader, Uig, Lewis, and the people who lived in his immediate neighbourhood, were on such friendly terms, that on the footing of that friendship the young "Fach Uisge" ventured ("dhol air cheilidh ") to pay a friendly visit to a near neighbour's house. Before he left, however, he and the good man of the house quarrelled. The man gave him a severe maul- 
ing. While he was thrashing him he nicknamed himself "Mifèin 'us Mi-füin" (Myself and Myself). The young "Each Uisge" went back to his father roaring with pain. The old "Each Uisge" asked him who had been at him. He replied: "Mi-fín 'us Mi. fiin " (Myself and Myself). The old "Each Uisge" said: "Nam' be duine eile gu'n deanadh is misi gu'n dioladh" ("If another one had done it, I would revenge it"). This threatening reply of the old "Each Uisge" is a common Lewis proverb, with the addition "Mar a thubhairt an Each Uisge" ("As the water-horse said.")

This legend is ethnologically interesting as having remarkable points of contact with the story of Ulysses and Polyphemus, Odyssey, Book ix. lines 365-410.

\section{VI.-A' Mhaideann-mhara. ('The Mermaid.)}

The sea-cattle-so says the legend-came ashore at Shawbost once upon a time. The mermaid followed them. When the people of the district saw them ashore, they hastened to get between them and the sea to sprinkle the landing-place with (Maighstir) urine. (Gun so a' difeanainh cha b' urrainn iad a bhi air an gleidheadh air tir.) Without performing this ceremony they could not be kept ashore. They then brought them to be housed at the nearest farmsteading. The mermaid followed them. They were kept ashore about a week. The mermaid was particularly reticent during her stay. She broke silence only once; the occasion was her observing the woman in whose house she stayed cleaning newly-caught fish. She said to her: "Nigh' us glan gu maith an tiasg a's ioma beast a tha 'sa mhuir" ("Wash and clean woll the fish, there is many a monster in the sea"). These words are in frequent use as a proverb, with the addition "Mar a thub hairt a' mhaid-eann-mhar" ("As the mermaid said.") To prevent the sea-cattle running away to their native element it was a sine qua non to sprinkle them with (Maighstir) urine every morning before letting them out to graze. One morning, however, this ccremony was neglected by the herd. The mermaid observed his mistake and her chance. She immediately ran down to the sen and began to call the sen-cattle by their several names, as follows:

"Ho! gu'n tig 'Stheag.' Hol gu'n tig 'Scothag.' IIoI gu'n tig "Crom-an-taoid"" (the Bend of the Rope). "Ho! gu'n 
tig Cadilteag-bhàn" (White Caoilteag). "Hol gu'n tig Donnach-mhdr-a'-bhainne bhruich" (Big Donnach of the cooked milk). O may "Stheag" come, \&c.

The sea-cattle ran down to the sea. When she saw them coming she exclaimed: "Tha mo chrodhsa'n so 'tighinn; ach ged thi'n crodh na thi'm buachaill." ("My cattle are here coming, but, though the cattle are coming let the herdman not come.") The herdman ran after them and caught the last of them by the tail as it plunged into the sea, but could not keep it. When the mermaid observed how the herd had behaved, she said:

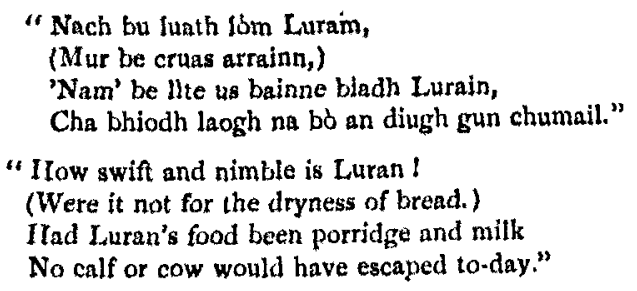

The legend says it was then that the people of that district began to use porridge as food.

\section{VII - Another Legend of the Mermaid.}

The crew of a Lewis boat were coming across the minch from Lochbroom. In mid-ocean they saw the mermaid rising at the helm. "Thubhairt fear de'n sgiopadh co luath s'a chunnaic i seun fala o'n a bheist," one of the crew said as soon as he saw her "blood-charm" from the monster. She went at once out of sight, but shortly thereafter rose again to the surface at the helm. " 'Us' thubhairt $i$ ris an stiureadair; le do churgair dubh air do lath-chrann cia do leth-rann," she said to the helmsman. ("With your little black hood on the side of your head, what is your half-stanza?") He replied: "Long a thig 'us a theid gu aithghearr, as e sin mo leth-rann" " A ship which is in keen touch with the helm": lit. a ship that goes and comes nimbly). "Is maith a chur sin ruit" ars ise, agus chaidh i fodha 'us chan thac iad tuilledh i. "It is well for you that you have so replied", said she, and disappeared, and they saw her no more). It was observed that when the mermaid was seen, under such circumstances as described above, it was a sure omen that drownings VOL. VIII. 
were to occur shortly in that neighbourhood, and so it happened our legend tells.

\section{VIII.-How the Straw Hillocks got their Name.}

There are two hillocks well known to the writer-in South Shawbost, Lewis-called " Id Chnoc na connlaich," i.e. the two straw hillocks. In ancient legend it is told that a person who happened to be passing between these two knolls, carrying a bundle of straw, late at night, heard when he was exactly between them a fairy from one of them calling him by his local name, thus: "Mhic Dhomhnuill Ghlais nach fagg thu 'Chonnlach," i.e. Son of Donald Gray, will you not leave the straw? Before, however, he had time to consider what to do he heard a fairy from the opposite hillock saying: "Mhic Dhomhnuill Ghlais cha'n fhàg thu Chonnlach co fada 'as a bhios uirread leat agus a tha 'na $d$ ' aghaidh agus duine bharrachd;" i.e. Son of Donald Gray, don't leave the straw so long as there are as many for you as there are against you and a man more.

These hillocks derived their name, so the legend tells us, from this well-known incident of the fairies of one hillock taking the part of a benighted pedestrian of the Adamic race against their neighbour fairies.

Malcolm MacPhail.

\section{Some Country Remedies and tileIR USES.}

The following are some remedies used by country folk in Fingland, but mainly in Ireland, which (or the majority of which) have not, so far as I am aware, been published yet. They have all come under my own notice or been procured by me from trustworthy sources.

Scarlct flannel, in E. Riding, Yorks, is the remedy for scarlet fever and other diseases where the idea of red is concerned. The moor-folk use it.

In 'Tipperary, an old woman will cure warts in a week by taking two straws from the thatch of a nuuse, crossing and laying them on 
the spot; the idea of the cross being involved, the spiritual sced of disease is believed to be cast out, and thus the visible signs must necessarily disappenr.

In Donegal, dog-fat is considered an excellent remedy for stiff joints.

In County Down, a plant popularly known as "Red Roger" is used to stop bleeding at the nose; probably the same idca being connected with it as with the scarlet flannel above mentioned.

$A$ band of silk worn round the neck is the preventive against quinsy, used by one gentleman in Shropshire and another in Dorsetshire, where I first heard of it.

In Tipperary, stolen meat rubbed on warts and then buried will cause them to disappear. Also in the same county and King's County, a wedding-ring rubbed on a sty in the eye is said to cure; but gold seems to have wondrous charms everywhere.

In King's County, the blood of a black cat, if drunk, is a cure for "wild fire." Cats have always been credited in Ireland, even from Celtic times, with mysterious powers.

About Lismore (Ireland), a plant known as "Poverty of the Ground" boiled with fresh milk is said to be a cure for hydrophobia.

In I. Yorks, among the moor-folk, the small hard sceds of Gromwell (Lithospermum officinale) is remedial for stone, when taken internally.

In County Down, nettles are widely used for paralysis of the limbs; continued excitement by them on the skin is the form of treatment.

In parts of Ireland, hemlock is used for giddiness. There is one man in E. Yorks. who uses the tongue of a fox as a poultice for removing a thorn from the finger.

In Fermanagh, nettle-tea (a decoction of the leaves and tips of Urtica urens) is the cure for measles.

In some parts of Ulster, Juncus glaucus is the supposed evictor of jaundice; but every district has an old man or woman who is considered capable of curing this, the visible sign of another ail. ment, and it must, I imagine, generally fail.

The bagbean and hazel are both said to share in the McGovern of Glans' cure for hydrophobia ; but this is believed to be a remedy hygienic and dietetic in a great measure.

In some parts of Ireland, we find what must be a torture rather 
than a cure practised on children often, i.e. common salt rubbed on a scald or burn, to heal.

In Queen's County and Tipperary, after a child has cut its first tooth, if a bunch of grass be rubbed over the gums it acts as a preventive against his or her being troubled by those which come later.

There is the root of one plant, an official remedy in the British Pharmacopceia as a demulcent in coughs, but which I have not heard of before being used as an aid for a weak stomach, and that is liquorice root (root of Glycerrhiza glabra), yet this is a Lancashire treatment.

Believe me, also, the Irishman trusts in a potato in his trouserspocket as a guard against rheumatism; and also in some parts of Ireland we find a poultice is sometimes made from chickweed (Alsine media) for drawing boils.

In King's County, the two following remedies are made use of : ivy lcaves heated till they become hot and soft, and placed and kept on continually, in the event of scalds; this I know to be recommended as a good cure.

Two or three ivy berries taken internally are still used for pains and aches in the above county, and also in the neighbouring ones.

In Tipperary, a poultice of onions is a well-known remedy for a sore throat.

The cough mixture of an old King's County family contains heather; and the leaves of the houseleek (Sempervivum) rubbed into sore eyes are believed remedial (Tipperary).

In Tipperary also, the leaves of a plant popularly known as the "Rose Noble," or "Stinking Roger," boiled, yield a splendid tonic.

Among the moor-folk of E. Riding, Yorkshire, an herb termed "Harb sanctuary," really the Red Centaury (Erythraa centaurea), of the gentianea is used as a stomachic; the same folk also use "Bluc Peter" (Aconitum napellus) for inflammation; we know it in one form as an ointment used in neuralgia and rheumatism.

Ranunculus acris, the leaves and flowers beaten to a pulp, and applied to suppurating tuberculosis, is remedial in Fermanagh, 'Tyrune, Donegal.

Senecio jacobcea leaves boiled or soaked in boiling water are often used as a poultice for abscess tound the nipple (Fermanagh). 
Orange lily root boiled to make a poultice for axillary tumours ; the root is boiled till soft, and the outer skin peeled off; a little ontmeal is added and the whole squeezed together (Cavan).

Nepeta glechoma-decoction used as an emmenagogue in chlorisis in some places (Ulster).

Sambucus nigra-decoction of the inner bark is used as a remedy for epilepsy; while being used, the attacks are said to be less frequent (Jreland).

Mud-remedy for wasp stings ; though I heard of this in South of Ireland, I believe it is common elsewhere.

Veronica beccabunga, boiled and sweetened with sugar candy, used as an expectorant about Belfast and neighbourhood.

Sonchus oleraceus-Sowthistle-has virtue in its juice, which is a cure for warts.

"Glarre poultice": the naind from the bottom of a boghole is used to make a poultice for suppurating corns; its properties are mainly antiseptic (North Ireland).

Peatmoss is now replacing oakum as dressing, and, I have heard, will soon probably do so entirely (Ireland, heard of from Fermanagh).

Alsine media (chickweed) heated well before a fire is applied to cure pains in the head and back of the neck (Londonderry).

The inner leaves of the common cabbage are considered remedial for drawing boils in Cheshire and Shropshire.

"Cumferry," as the folk of Wexford call a plant which, from the description I obtained of it, I think is comfrey (Symphifum officinale); the roots boiled down are applied externally for everything from a cold down to a sprained ankle, and are widely used.

The ashes of a burnt briar are supposed to heal cuts, if laid on them, in King's County, as also in the same county lime and sweetoil are believed remedial in erysipelas; mix unslaked lime with the best sweet-oil and rub with the mixture over the affected parts.

Fresh milk is used to draw out the spots of measles; the body is washed with it (King's County).

Nettles used for rheumatism by continual excitement externally in Queen's County.

A wet handkerchief tied round a sore throat at night when going to bed is considered an excellent remedy in County Down. 
One case is known in Monaghan where wrapping a man in brown paper and vinegar cured him of scarlatina.

A wedding-ring in some parts of Ireland is said to curc "wild fire," and a blue ribbon round the neck acts as a charm against croup.

Jandy Well. Dip in this well, which is in Monaghan, and hang rags about it, and if you have jaundice you will get well. The people of this part pronounce jaundice as "jandice," or " jandy."

One man in Ulster dipped in a bog-hole at midnight, and in three or four days was cured of erysipelas; this is related as a fact.

Buttermilk is used as a cure for ringworm by country-folk in many districts now ; it was used for this purpose over fifty years ago in Scotland.

Poteen : the first running is used in Ireland in various parts for rheumatism.

In King's County, near Templeharry (about two miles from Cloughjordan), are some "Old Ruins," which are believed to be the remains of a monastery, though the people are not sure about it. Here there is a hollow tree which always has water in it; if you have a wart, in order to get rid of it, you have only to wash in the water and it will disappear.

\section{I, Hamilton Villas, Ballyholme, Bangor, Co. Down, Ireland.}

JOIIN HI. BARLOUR.

\section{Tur Painswick Doo-pre.}

On Painswick feast-day, which is kept on the first Sunday after September Igth, it used to be a general custom for people to partake of plum-pies in which the china figure of a dog had been baked. No one owns to following the custom now; but if any do so, they make the pics at home, an ordinary meat pie such as is made in any household, with the dog inside it. It was not necessary that the pie should be a plum-pie, so long as a china dog was inside. I have been trying for a long time, without success, to get one of these little figures. Miss Mendham, of 
Clifton, has been fortunate enough to obtain one from a young woman after the last feast-day; and I thereupon asked her permission to show it to the members of the Society. I understand from her that this little figure was served in a pie last autumn; there were several other similar dogs in this pie, one of them being a very small one. Miss Mendham also promised to try and interview the old man in whose house the pie was made, and who, she has been told, always keeps up the custom.

I tried some years ago to obtain some information as to the origin of the custom, but I could only obtain some more or less ridiculous stories about it. One correspondent said, "I know very little about 'Bow-wow cakes.' Thirty years ago 'Bow-wow cake-day' was kept nearly universally, but now the custom is almost dead, nobody seems to keep it up. Any cake or pie will do, so long as there is a small china dog baked with it. The day was kept on Painswick feast-day." He also says, "Any china dog will do, one from the first toy-shop. You remember the oldfashioned china ornaments on cottage mantel-pieces, usually a shepherdess, a lamb, and a $\operatorname{dog}$ ? Well, the dog would go into the cake." " $\Lambda \mathrm{s}$ to the origin," this gentleman continues, "there is a tale that some 'Gothamites' from Stroud came to Painswick and ordered a meat-pie. This was duly prepared, but unfortunately got eaten by mistake by some other folks who had not ordered it; and as there was no more meat to be had at the village butcher's, a poor dog was slaughtered and made into a pie for the strangers. This gave rise to the origin of the feast, and to the circumstance that the Painswick people have since been called 'bow-wows,' and should you say (at Stroud) 'that you were going to dine at Painswick,' it was usual to reply 'On dog?'"

Mr. U. J. Davis sent me (through the Rev. W. S. Guest Williams) another story: "At the Lamb Inn, in Bisley Street, many of the navvies engaged in making the new road between Cheltenham and Bath at the beginning of this century lodged. They were a low, rough, vulgar lot of fellows, who were the terror of the neighbourhood and the bugbear of the landlady of the Lamb. It was their special delight and boast 'to eat her out of house and home ;' and the poor woman, especially on a Sunday, had the greatest difficulty in satisfying the voracious appetites of these formidable gluttons. At last she resolved to put an end to her troubles and rid herself of her gluttonous, drunken guests. 
On the Feast Sunday she made a pie of dog's flesh; and when the navvies had eaten it she then told them what they had had for dinner, with what result nceds no telling. To say "bow-wow," or to imitate the bark of a dog, in any street of Painswick was the sure forerunner of a breach of the peace. Occasionally still, on Feast Sunday, a meat-pie is made, within which is placed a china dog, to keep up the remembrance of the 'bow-wow' pie; but the custom is dying out, and it would be well to bury it in oblivion."

Another story is, that on one of the church feast-days in years gone by the Painswick people invited their neighbours of Stroud to a venison-feast (red deer were said to be plentiful in those days on the Cotswold Hills). The venison was not forthcoming, and Painswick was in despair at not being able to furnish the proper feast. It was suggested that they could save their reputation by serving up dog-pie instead. When the guests discovered the trick, a tremendous fight ensued. The Painswick people conquered, and instituted the feast in honour of their victory; but making plum-pie with a china dog baked in it answers instead of dog itself.

The Rev. W. S. Guest Williams also stated that he had heard that a tradition may have been handed down from pre-Christian times of a British festival in which dogs figured in some form. I have not heard of any tradition to this effect, but there certainly may be one. The connection of this "bow-wow pie" observance with the dedication-festival of the parish church, which the Painswick feast day really is, and with another custom which a correspondent tells me formerly terminated the feast day's proceedings--mat of encircling or encompassing the church by all the villagers joining hands, then swaying backwards and forwards, and finally dancing round and singing-points to the survival of a local cult of a more primitive origin than these modern accounts.

An important point to notice, and one which appears in each of the stories told, is that people of two different parishes are concerned in the quarrel, and that a fight between them occurs.

A. B Gомme. 


\section{FOUR Yorkshire Folktales.}

\section{1.-The Old Man at the White House.}

There was once a man who lived in a white house in a certain village, and he knew everything about everybody that lived in the place.

In the same village there lived a woman who had a daughter called Sally, and one day she gave Sally a pair of yellow kid gloves and threatened to kill her if she lost them.

Now Sally was very proud of her gloves, but she was careless enough to lose one of them. After she had lost it she went to a row of houses in the village and inquired at every door if they had seen her glove. But everybody said "No;" and she was told to go and ask the old man that lived in the white house.

So Sally went to the white house and asked the old man if he had seen her glove. The old man said: "I have thy glove, and I will give it thee if thou wilt promise me to tell nobody where thou hast found it. And remember if thou tells anybody I shall fetch thee out of bed when the clock strikes twelve at night." So he gave the glove back to Sally.

But Sally's mother got to know about her losing the glove, and said: "Where did thou find it ?"

Sally said: "I daren't tell, for if I do an old man will fetch me out of bed at twelve o'clock at night."

Her mother said: "I will bar all the doors and fasten all the windows, and then he can't get in and fetch thee;" and then she made Sally tell her where she had found her glove.

So Sally's mother barred all the doors and fastened all the windows, and Sally went to bed at ten o'clock that night and began to cry. At eleven she began to cry louder, and at twelve o'clock she heard a voice saying in a whisper, but gradually getting louder and louder:

$$
\begin{aligned}
& \text { "Sally, I'm up one step." } \\
& \text { "Sally, I'm up two steps." } \\
& \text { "Sally, I'm up three steps." } \\
& \text { "Sally, I'm up four steps." }
\end{aligned}
$$

'From Waikefield. Told to me by C. R. Ilirst, of Shefficld, aged is. It is hoped that this tale will not be reprinted in any bonk intended for children. 


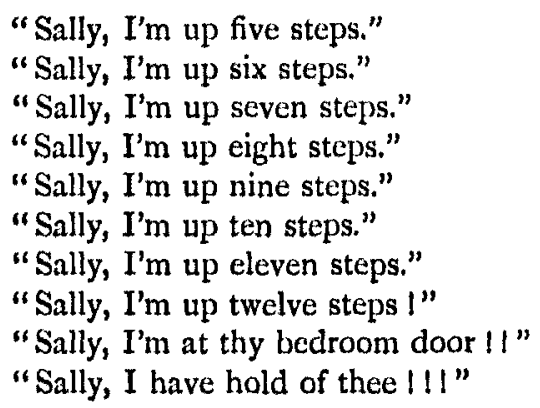

\section{IT.-The Satin Frock.}

There was once a little girl called Mary who had a satin frock, and her mother told her that if she got a dirty mark on it she would kill her. One day as Mary was going a walk, some cows that were passing by splashed her frock with mud. Then Mary went and sat on a doorstep and began to cry. The woman in the house hearing her cry came out, and Mary told her that she dare not go home because she had got her frock dirty, and that her mother had threatened to kill her if she got it dirty. So the woman took her in and washed the mud from her frock, and then dried it. She then sent the little girl on her way, telling her to mind and not get it dirty again, and then her mother would not kill her. So Mary went on her way, but lower down the road a horse that was running by splashed her frock again. When she got home her mother took her in the cellar and cut her head off, and hung it on the wall. When her father came home he said: "Where is our Mary ?" Her mother told him she had gone to her grandmother's to stay all night. When bed-time came he said: "I will fetch the sticks up;" but his wife said: "No, I will ;" but he said: "No, I will fetch them up;" and she said: "No, I will ; "but he would not let her fetch them. When he had got down in the cellar he saw the head hung up, so when he had come out of the cellar he asked his wife what it was. She told him that it was a sheep's head that she was going to make some broth of for to-morrow's dinner. When he came home to dinner next day, he said: "This broth is nice, but it does taste like our

1 Told to $C$. R. Ilirst in Sheffield by a girl aged about 13 , and repented by him to me, June, 1896 . 
Mary." When his wife heard this she was very frightened; but when her husband found out what had been done he took her in the cellar and killed her.

\section{III.-Nicorbore. ${ }^{1}$}

One day in winter-time, when there was a large quantity of snow on the ground, Nicker happened to be going along that narrow road leading from Gleadless to Norton, and walking in the middle of the road, where of course would be the best track, perhaps the only one. At the same time a gentleman was coming swiftly along on horseback in the opposite direction. He saw the man in front of him, but rode on, expecting of course he would give way, but not so. Nicker stuck to his track, and the gentleman had to pull up very suddenly out of his way.

"What fool are you?" demanded the gentleman angrily.

"Au'm Captain Stones's fool-whose fool ar' tha?" retorted Nicker.

I have been told that sixty or seventy years ago Nicker Bore's name was bandied about amongst. Mosbro' people like the name of Jim Garton, late of Beighton, has been in Beighton of late years. ${ }^{2}$

\section{IV.-The Farmer and his Man."}

One day a farmer was walking round his farm, when he heard his man singing in a barn. So he stopped to listen, and heard these words :

$$
\begin{aligned}
& \text { "Bread and cheese, work as you please, } \\
& \text { Bread and cheese, work as you please." }
\end{aligned}
$$

The farmer then went and told his wife what he had heard.

1 From George Foster, Queen Street, Rotherham. Sent to me by Sir George R. Sitwell, Bart., 24 October, 1895 . This is a frngment af one of the numerous tales once current nhout Nicorbore. See my Klowsehold Tales, soc, p. 37.

- Captain Stones lived at Mosborough, near Eckington, in Derbyshire, not far from Renishaw IIall, the seat of Sir George R. Sitwell. Gleadless, Norton, and Beighton are in the same neighbourhood, "Jim Garton" nppears to be a mythical name, but I will make inquiries about him.

- Told to Mrs. S. O. Addy in Sheffield by a nurse, about twenty-five years ago. 
The farmer's wife said: "How did he seem to be working?"

"Oh," he said, "I peeped through a loop-hole in the barn, and he didn't see me, but I saw him; and he was working as slowly as he could."

"That'll never do," she said; "I'll try him with something better than that."

So the next day she made a nice plum pudding and an apple pie for the man. Then she told her husband to go and see if he worked any better.

So this time the farmer heard him singing :

$$
\begin{aligned}
& \text { "Plum pudden and apple pie, } \\
& \text { Do your work accordingly. } \\
& \text { Plum pudden, \&c." }
\end{aligned}
$$

So the farmer went back to his wife, and told her what he had heard.

"How was he working?" she said.

"Much better, but not so fast as he might do," he replied.

"Oh, well," she said, "I'll try him with better food than that." So the next day she gave him roast beef and plum pudding, and told her husband to go and see if he worked any better.

So this time the farmer heard him singing :

$$
\begin{aligned}
& \text { "Roast beef and plum pudden, } \\
& \text { Do your work like a good un. } \\
& \text { Ronst beef, \&c." }
\end{aligned}
$$

Then the farmer told his wife what he had heard, and said the man was working as hard as a horse and with all his might.

So after this the farmer's wife always fed the man on the best food that she could get, and he worked hard ever after.

S. O. ADny. 